http://heanoti.com/index.php/hn

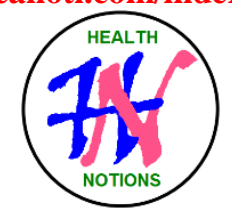

RESEARCH ARTICLE

URL of this article: http://heanoti.com/index.php/hn/article/view/hn30103

\title{
In vitro Inhibitory Activity of Ethanolic Fruit Extract from Averrhoa bilimbi L. against
} Streptococcus pyogenes Bacteria

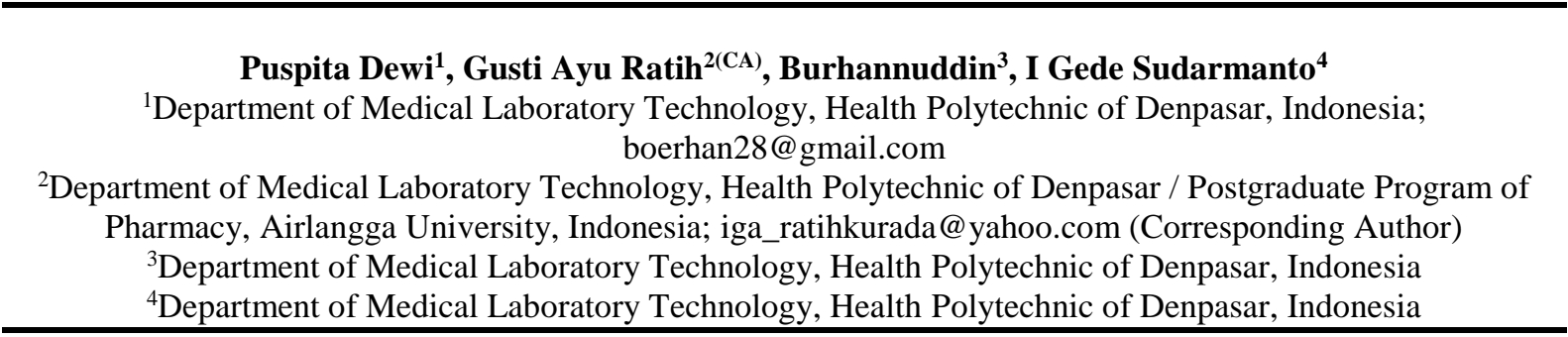

\begin{abstract}
Averrhoa bilimbi L., popularly known as belimbing wuluh, is a common plant used as traditional medicine and cooking ingredients in Indonesia. Averrhoa bilimbi fruit contains many active substances as antibacterial such as tannin, formic acid, flavonoids, saponins, peroxides, and triterpenoids. Streptococcus pyogenes is a pathogenic bacteria that can cause respiratory infections. This study was carried out to investigate the inhibitory activity of Averrhoa bilimbi L. fruit extract at various concentrations on the growth of Streptococcus pyogenes. This study was a true experimental with post test only control design. The inhibitory activity was assessed by the KirbyBauer's disc diffusion method with four different extract concentrations $(20 \%, 40 \%, 60 \%, 80 \%), 96 \% \mathrm{EtOH}$ as negative control, and Amoxicillin antibiotic as positif control. The EtOH extract showed the mean diameter of inhibition zone of $20 \%$ extract was $11.43 \mathrm{~mm}$ (strong), $40 \%$ extract was $19.13 \mathrm{~mm}$ (strong), $60 \%$ extract was $24.58 \mathrm{~mm}$ (very strong), $80 \%$ extract was $30.99 \mathrm{~mm}$ (very strong), and the negative control (96\% EtOH) was 0.00 $\mathrm{mm}$. Least Significant Difference test showed there were significant different of inhibition zone in each extract concentrations of Averrhoa bilimbi L. against Streptococcus pyogenes with the strongest inhibitory activity is $80 \%$ extract concentration.
\end{abstract}

Keywords: Averrhoa bilimbi, Inhibitory activity, Streptococcus pyogenes

\section{INTRODUCTION}

\section{Background}

Averrhoa bilimbi (Family Oxalidaceae) is popularly known as belimbing wuluh, is a common plant used as traditional medicine and cooking ingredients in Indonesia. This plant is widespread across Indonesia, Malaysia and as exotic in Argentina, Australia, Brazil, Colombia, Cuba, Ecuador, Guyana, India, Jamaica, Myanmar, Philippines, Puerto Rico, Singapore, SriLanka, Surinam, Tanzania, Thailand, Trinidad \& Tobago, US, and Venezuela. Fruit ellipsoid, obovoid or nearly cylindrical, faintly 5-sided, 4-10 cm long, capped by a thin, starshaped calyx at the stem-end and tipped with 5 hair like floral remnants at the apex. Crispy when unripe, the fruit turns from bright green to yellowish-green, ivory or nearly white when ripe and falls to the ground. The outer skin is glossy, very thin, soft, juicy and extremely acid $^{(1)}$.

A. bilimbi has been used in the traditional medicine for the treatment of a variety of ailments. Infusions and decoctions of the leaves are used as an antibacterial, antiscorbutic, astringent, postpartum protective medicine, in the treatment of fever, inflammation of the rectum, and diabetes ${ }^{(2)}$. Fruit juice is used in the treatment of scurvy, bilious colic, whooping cough, hypertension, obesity, and diabetes ${ }^{(3,4,5)}$. Several studies have found that $A$. bilimbi contains high amount of bioactive compounds. Preliminary phytochemical studies of the fruit extracts using chemical methods and thin layer chromatography revealed the presence of carbohydrates, proteins, amino acids, flavonoids, tannins, bitter principles, essential oil, valepotriates, coumarin, and terpenes ${ }^{(6,7)}$. The bark extracts of A. bilimbi revealed moderate antibacterial activity against some microorganisms and the phytochemical investigation suggested the presence of flavonoids, saponins and alkaloids ${ }^{(8)}$. The leaves and fruit extract of $A$.

13 | Publisher: Humanistic Network far Science and Technology 
bilimbi also contains a number of flavonoids with the type of luteoin. This compound, together with apigenin is known to be effective enough to inhibit the growth of several types of bacteria such as Bacillus cereus and Corney bacterium diphteria $^{(9)}$. The fruits are also rich in Vitamin $\mathrm{C}$ and oxalic acid ${ }^{(6,7)}$. The previously study also reported that the content of oxalic acid in Averrhoa species can become a potent source of antioxidant and antimicrobial against S. aureus ${ }^{(10)}$. The aqueous and chloroform extracts of A. bilimbi's leaves and fruits $(100 \mathrm{mg} / \mathrm{ml}) \mathrm{showed}$ a positive antibacterial activity against Staphylococcus aureus, Staphylococcus epidermis, Bacillus cereus, Salmonella typhi, Citrobacter freundii, Aeromonas hydrophila, Proteus vulgaris, and Kocuria rhizophila ${ }^{(11)}$. In another study, fruits and roots extracts of A. bilimbi were also found to exhibit the positive activity against Mycobacterium tuberculosis with MIC of $1600 \mu \mathrm{g} / \mathrm{ml}^{(12)}$. The previously study also reported that EtOH extract of A. bilimbi fruit inhibits the growth of Streptococcus mutans with the mean diameter of inhibition zone formed at concentration of $25 \%$ was $10.1 \mathrm{~mm}, 50 \%$ was $15.1 \mathrm{~mm}, 75 \%$ was $18.1 \mathrm{~mm}$, and $100 \%$ was $20.1 \mathrm{~mm}^{(13)}$.

\section{Purpose}

The aim of current study was to analysis the inhibitory activity of Averrhoa bilimbi L. fruit extract at various concentrations on the growth of Streptococcus pyogenes by using in vitro techniques. The concentration variations used in this study were $20 \%, 40 \%, 60 \%$, and $80 \%$. This concentration variation is based on the preliminary test that has been carried out. Concentration of $20 \%$ extract produces a zone of inhibition of $10 \mathrm{~mm}$, so the concentrations of $20 \%, 40 \%, 60 \%$, and $80 \%$ are chosen in this study.

\section{METHODS}

The inhibitory activity was assessed by the Kirby-Bauer's disc diffusion method with four different extract concentrations $(20 \%, 40 \%, 60 \%, 80 \%), 96 \%$ EtOH as negative control, and Amoxicillin antibiotic as positif control. The method of this research used True Experimental. The research design used Posttest Only Control Group Design ${ }^{(14)}$. Unripe Averrhoa bilimbi L. fruit (green to yellowish green) with a size of 4-5.6 cm were collected from local area of Denpasar district-Bali, and authenticated by an expert botanist from Udayana University, Bali. Inhibitory activity was evaluated by measuring inhibition zone diameters. Data analysis began with the Kolmogorov Smirnov test, then One Way ANOVA test was used to determine the inhibition zone and LSD (Least Significant Deference) was used to determine the inhibitory zone variation between each concentration of $A$. bilimbi fruit EtOH extract. The time of the study began on June $1^{\text {st }}$ to August $31^{\text {st }}, 2018$.

\section{RESULTS}

\section{Inhibition zone of Averrhoa bilimbi L. fruit extract against Streptococcus pyogenes bacteria growth}

In this study the inhibitory test of A. bilimbi fruit extracts concentrations of $20 \%, 40 \%, 60 \%$ and $80 \%$ was carried out on the growth of Streptococcus pyogenes bacteria using $96 \% \mathrm{EtOH}$ as a negative control and Amoxicillin $25 \mu \mathrm{g}$ as a positive control.

Table 1. Zone of inhibition of A. bilimbi fruit extract at various concentrations on the growth of Streptococcus pyogenes using the Kirby-Bauer's disc diffusion.

\begin{tabular}{|c|c|c|c|c|}
\hline \multirow[t]{2}{*}{ Extract/Control } & \multicolumn{2}{|c|}{$\begin{array}{c}\text { In vitro assays } \\
\text { Inhibition Zone } \pm \text { Standard Deviation }\end{array}$} & \multirow{2}{*}{$\begin{array}{l}\text { Mean of Inhibition } \\
\text { Zone } \pm \text { Standard } \\
\text { Deviation }(\mathrm{mm})\end{array}$} & \multirow[t]{2}{*}{ Category } \\
\hline & Replication I & Replication II & & \\
\hline $20 \%$ & $11.7 \pm 0.46$ & $11.15 \pm 0.10$ & $11.42 \pm 0.26$ & Strong \\
\hline $40 \%$ & $19.95 \pm 0.06$ & $18.30 \pm 0.23$ & $19.12 \pm 0.14$ & Strong \\
\hline $60 \%$ & $25.05 \pm 0.06$ & $24.10 \pm 0.84$ & $24.57 \pm 0.42$ & Very strong \\
\hline $80 \%$ & $29.10 \pm 0.49$ & $32.87 \pm 0.25$ & $30.99 \pm 0.30$ & Very strong \\
\hline Positive control & $35.00 \pm 0.0$ & $36.40 \pm 0.0$ & $35.70 \pm 0.0$ & Sensitive \\
\hline
\end{tabular}

Values represent mean \pm standard deviation, $\mathrm{n}=4$.

The mean diameter of negative controls showed there was none inhibitory activity of Streptococcus pyogenes bacteria growth. The result of the largest inhibition zone was produced by $80 \%$ extract concentration which was equal to $30.99 \mathrm{~mm}$, while the smallest diameter was obtained from $20 \%$ extract concentration which was $11.43 \mathrm{~mm}$. The results of minimum inhibitory zone diameter and its inhibitory category are presented in Table 1. The inhibitory activity of $A$. bilimbi fruit extracts at concentration of $20 \%$ and $40 \%$ was categorized as strong inhibition because it has a diameter of inhibition zone 10-20 mm. While the inhibition of $A$. bilimbi fruit extracts at concentration of $60 \%$ and $80 \%$ was categorized as very strong with diameter of the inhibition zone $>20 \mathrm{~mm}$. 


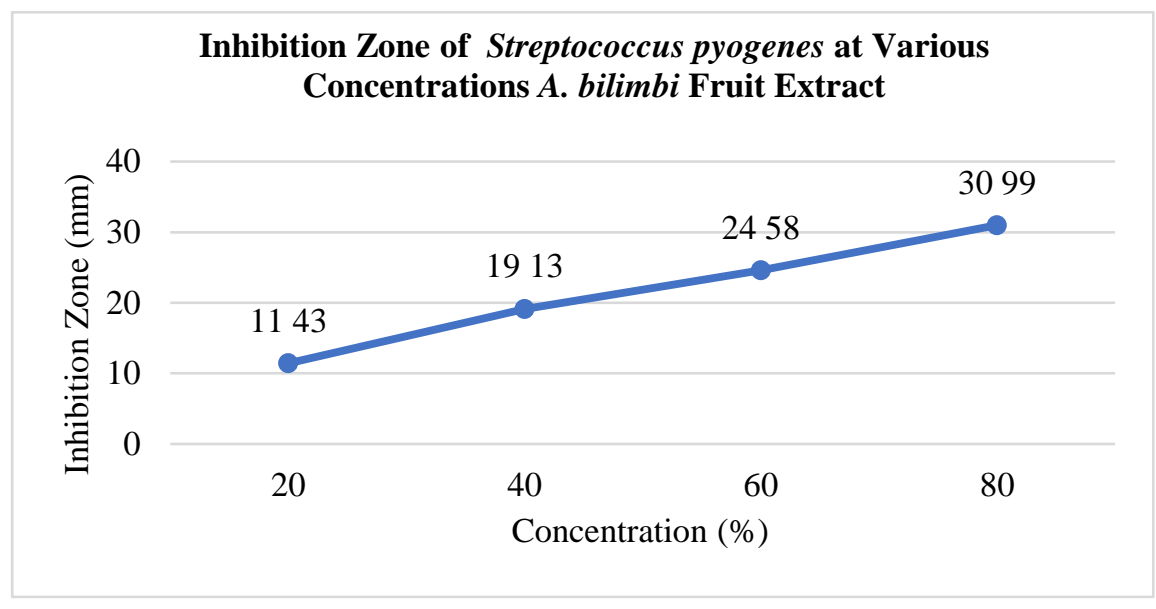

Figure 1. Inhibition Zone Differences of Averrhoa bilimbi L. fruit extract at various concentrations
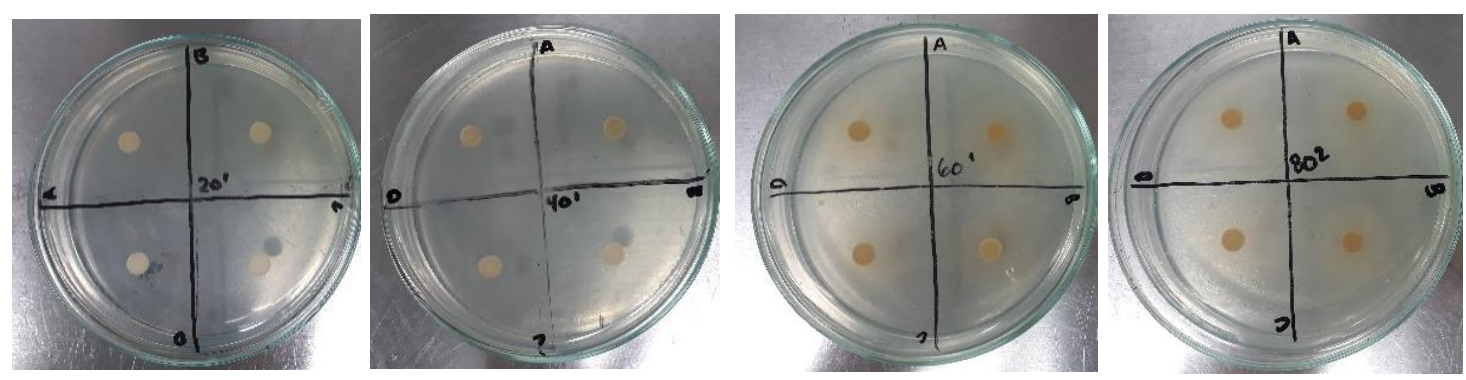

Figure 2. Diameter of inhibition zone at concentration of $20 \%, 40 \%, 60 \%$, and $80 \%$ of $\mathrm{A}$. bilimbi fruit extracts

\section{Data analysis of differences inhibitory activity of Averrhoa bilimbi L. fruit extract}

The Kolmogrov Smirnov test results obtained p-value was $0.476(>0.05)$, than the p-value of One Way Anova test was $0.000(<0.05)$. The results shown there was a differences inhibition zone of Streptococcus pyogenes bacteria growth at various concentrations of $A$. bilimbi fruit extract. The differences of inhibitory activity from various concentrations was analyzed by LSD test. The LSD test showed that $p$-value was $0.000(p<\alpha)$, there were significant differences between each of the extracts concentration.

\section{DISCUSSION}

The inhibitory test was conducted to determine the antibacterial potential of Averrhoa bilimbi L. against Streptococcus pyogenes bacteria. A. bilimbi fruit extract was obtained through maceration method using $96 \%$ $\mathrm{EtOH}$, the extract obtained then tested for its inhibitory avtivity at various concentrations with the Kirby-Bauer diffusion method. Based on the results of the observation, all the concentrations of the ethanol extract of $A$. bilimbi fruit have inhibition on the growth of Streptococcus pyogenes bacteria. Inhibition can be seen from the clear zones that formed around the disk containing A. bilimbi fruit extract. In this method, the extract on the disk will diffuse and the active substances contained in it will inhibit bacterial growth. The wider the clear zone formed shows the greater inhibitory activity. In this study, $96 \%$ ethanol was used as a negative control to determine whether there is an effect of ethanol on the growth of Streptococcus pyogenes bacteria which is also used as a solvent in the extraction process. The mean diameter of negative controls showed there is no inhibitory activity of Streptococcus pyogenes bacteria growth with a measured value of $0.00 \mathrm{~mm}$. The same thing was also obtained from the study ethanol extract and decoction of Myrmecodia sp.on Escherichia coli Bacteria ${ }^{(15)}$.

In this study, the positive controls used Amoxicillin antibiotic discs as work controls. Amoxicillin is a broad-spectrum antibiotic that is widely used to treat human and animal diseases, which is included in the class of penicillin ( $\beta$-lactam antibiotics). This antibiotic has been proven effective against various types of infections caused by gram-positive and gram-negative bacteria and used to treat and prevent respiratory, gastrointestinal, urinary and skin bacterial infections due to its pharmacological and pharmacokinetic properties ${ }^{(16)}$. The mean diameter of the inhibition zone from Amoxicillin antibiotic discs was $35.70 \mathrm{~mm}$. These results are according to 
CLSI (Clinical and Laboratory Standards Institute), where Amoxicillin belongs to the sensitive category. It is indicated the bacterial isolates used and the procedures carried out in this study are confirmed with testing standards for inhibiting antibacterial substances ${ }^{(17)}$. This study also shows that Amoxicillin is still effective against Streptococcus pyogenes bacteria, with a minimum inhibition zone diameter of $>24 \mathrm{~mm}^{(17)}$.

The results of this study shows that the fruit extracts of $A$. bilimbi at various concentrations were able to inhibit the growth of Streptococcus pyogenes which was characterized by the formation of clear zones around the discs. Inhibition activity is divided into four categories: inhibiting weak $(<5 \mathrm{~mm})$, medium $(5-10 \mathrm{~mm})$, strong (10$20 \mathrm{~mm})$, and very strong $(>20 \mathrm{~mm})^{(18)}$. The concentration of $20 \%(11.43 \mathrm{~mm})$ and $40 \%(19.13 \mathrm{~mm})$ have a strong inhibitory activity; $60 \%(24.58 \mathrm{~mm})$ and $80 \%(30.99 \mathrm{~mm})$ have very strong inhibitory activity. This study also shows that different diameter inhibition zones are formed for each concentrations. It might be caused A. bilimbi fruit contains various active compounds as antimicrobial properties such as flavonoids, alkaloids, tannins, and saponins; and antioxidant agent such as oxalic acid ${ }^{(10,19)}$. Oxalic acid also reported effective in reducing initial populations and controlling growth of spoilage bacteria on raw chicken breasts ${ }^{(20)}$. The previously study also reported that the content of oxalic acid in Averrhoa species can become a potent source of antioxidant agent and antimicrobial against $S$. aureus $^{(10)}$. The presence of the inhibition zone in this study indicates that extracts from unripe fruits contains of bioactive compounds that might be contribute to the antimicrobial properties of the fruits. The previously study reported the extracts from A. bilimbi unripe fruits are more effective against against Salmonella $\operatorname{spp}^{(21)}$. This is similar to the result of the present study where the microbiological stability of some fruits and vegetables can be attributed in part to the presence of oxalic acid. The antibacterial effect of oxalic acid is attributed to a reduction in the extracellular $\mathrm{pH}$ and cellular uptake of the undissociated form of the acid. This uptake results in intracellular $\mathrm{pH}$ imbalance and subsequent death of the bacteria cell ${ }^{(20)}$. Figure 1 shows that the higher the concentration, the inhibitory zone formed becomes wider. The similar result was reported in the study of the inhibitory activity of Binahong Leaf (Anredera cordifolia (Ten.) Steenis extract against Streptococcus pyogenes $^{(22)}$. Factors that can influence the differences of inhibition zone are media thickness and concentration of active substance in the extract ${ }^{(23)}$.

\section{CONCLUSION}

Based on the results of the research, it can be concluded that Unripe A. bilimbi fruit extract at various concentrations were able to inhibit the growth of Streptococcus pyogenes. The mean diameter of the largest inhibition zone was produced by $80 \%$ extract concentration with very strong inhibition category, while the smallest diameter was produced by $20 \%$ extract concentration with strong inhibition category. That might be caused $A$. bilimbi fruit contains various active compounds as antimicrobial properties and antioxidant agent, especially the presence of oxalic acid. There was a significant differences between the inhibition zones of the growth of Streptococcus pyogenes bacteria at the various concentrations of $20 \%, 40 \%, 60 \%$, and $80 \%$.

\section{REFERENCES}

1. Samtosa R. Miraculous Concoction of Powerful Efficacy (Ramuan Ajaib Berkhasiat Dahsyat). Yogyakarta: Pinang Merah; 2014.

2. Ganders FR. The Biology of Heterostyly. N Z J Bot. 1979;17:607-635.

3. Goh S, Chuah C, Mok J, Soepadmo E. Malaysian Medicinal Plants for The Treatment of Cardiovascular Diseases. Malaysia: Pelanduk Publications; 1995:62-63.

4. Ong HC, Nordiana M. Malay Ethno-Medico Botany in Machang, Kelantan, Malaysia. Fitoterapia. 1999;70:502-513.

5. Alsarhan AN, Sultana N, Kadir MR, Aburjai T. Ethnopharmacological Survey of Medicinal Plants in Malaysia, The Kangkar Pulai Region. Int J Pharmacol. 2012; 8: 679-686.

6. Hasanuzzaman M, Ali MR, Hossain M, Kuri S, Islam MS. Evaluation of Total Phenolic Content, Free Radical Scavenging Activity and Phytochemical Screening of Different Extracts of Averrhoa bilimbi (Fruits). Int Curr Pharm J. 2013;2:92-96.

7. Patil AG, Koli SP, Patil DA. Pharmcognostical Standardization and HPTLC Fingerprint of Averrhoa bilimbi (L.) Fruits. J Pharm Res. 2013;6:145-150.

8. Siddique KI, Uddin MMN, Islam MS, Parvin S, Shahriar M. Phytochemical Screenings, Thrombolytic Activity and Antimicrobial Properties of The Bark Extracts of Averrhoa bilimbi. Journal of Applied Pharmaceutical Science. 2013;3(03):094-096.

9. Akbar R. Various Pharmacy Plants Live Around Us Ed I (Aneka Tanaman Apotek Hidup di Sekitar Kita Edisi I). Edited by Cahyono. 2015.

10. Sripanidkulchai B, Tattawasart U, Laupattarakasem P, Wongpanich V. Anti Imflammatory and Bactericidal Properties of Selected Indigenous Medicinal Plants Used for Dysuria. HDi J Pharm Sci. 2002;26:33-38. 
11. Zakaria ZA, Zaiton H, Henie EF, Jais AM, Zainuddin EN. In Vitro Antibacterial Activity of Averrhoa bilimbi L. Leaves and Fruits Extracts. Int J Trop Med. 2007;2:96-100.

12. Mohamad S, Zin NM, Wahab HA, Ibrahim P, Sulaiman SF, Zahariluddin AS. Antituberculosis Potential of Some Ethnobotanically Selected Malaysian Plants. J Ethnopharmacol. 2011;133:1021-1026.

13. Rahmiati A. Inhibitory Potensial of Wuluh Starfruit Extract (Averrhoa bilimbi L) Against Streptococcus Mutans Bacteria Growth In Vitro (Daya hambat Ekstrak Buah Belimbing Wuluh (Averrhoa bilimbi L) Terhadap Pertumbuhan Bakteri Streptococcus mutans Secara In Vitro). Jurnal Penelitian dan Kajian Ilmiah Kesehatan, 2016;2(2):55-62.

14. Sugiyono. Qualitative Quantitative Research Methods and R \& D (Metode Penelitian Kuantitatif Kualitatif dan R\&D). Bandung: ALFABETA; 2012.

15. Roslizawaty, Ramadani NY, Fakhrurrazi, Herrialfian. Antibacterial Activity of Ethanol Extract and Ants Nest Decoction (Myrmecodia sp.) Against Escherichia coli Bacteria (Aktivitas Antibakterial Ekstrak Etanol dan Rebusan Sarang Semut (Myrmecodia sp .) Terhadap Bakteri Escherichia coli). Jurnal Medika Veterinaria. 2013;7(2):91-94.

16. Elizalde A, Velázquez, Gómez O, Galar M, Flores I. World's Largest Science, Technology \& Medicine: Amoxicillin in The Aquatic Environment, Its Fate and Environmental Risk. Wasington DC: Intech; 2016:248-267.

17. Clinical and Laboratory Standards Institute. M100 Performance Standards for Antimicrobial Susceptibility testing. 27th edn. Edited by L. Megan and M. Tertel. West Valley Road USA: 2017.

18. Davis WW, Stout TR. Disc Plate Method of Microbiological Antibiotic Assay. Applied and Enviromental Microbiology. 2009;22(4):666-670.

19. Gendrowati F. Family Medicinal Plants (TOGA Tanaman Obat Keluarga). Edited by Geulis. Jakarta Timur: Padi; 2015.

20. Anang DM, Rusul G, Radu S, Bakar J, Beuchat LR. Inhibitory Effect of Oxalic Acid on Bacterial Spoilage of Raw Chilled Chicken. Journal of Food Protection, 2006;69(8):1913-1919.

21. Mokhtar SI, Nur AAA. Antimicrobial Properties of Averrhoa bilimbi Extracts at Different Maturity Stages Seri. J Medical Microbiology \& Diagnosis. 2016;5(3).

22. Virgianti DP, Purwati DM. Inhibitory Activity of Ethanol Extract of Binahong Leaf (Anredera cordifolia (Ten.) Steenis) Against Streptococcus pyogenes Bacteria in In Vitro (Daya Hambat Ekstrak Etanol Daun Binahong (Anredera cordifolia (Ten.) Steenis) Terhadap Pertumbuhan Bakteri Streptococcus pyogenes Secara In Vitro. Jurnal Kesehatan Bakti Tunas Husada; 2015:13(1);24-27.

23. Brooks GF, Carroll KC, Butel JS, Morse SA, Mietzner TA. Medical Microbiology (Mikrobiologi Kedokteran). 25th Ed. Jakarta: Buku Kedokteran EGC; 2012. 